\title{
THE DEVELOPMENT OF PROFESSIONAL FLIP PDF BASED LEARNING MEDIA IN THEMATIC LEARNING AT THE THIRD GRADE STUDENTS OF ELEMENTARY SCHOOL
}

\author{
Siti Fatonah ${ }^{1}$, Teguh Yunianto ${ }^{2}$ \\ 1,2Universitas Islam Negeri Sunan Kalijaga Yogyakarta \\ 1,2Jalan Marsda Adisucipto, Yogyakarta, Indonesia \\ Email: sitifat317@gmail.com² ${ }^{1}$ teguhyunianto96@gmail.com²
}

\begin{abstract}
:
Thematic learning requires teachers' creativity in selecting and developing learning media; one of them is by using professional flip pdf learning media. This study aimed to determine the feasibility and investigate teachers' and students' responses towards professional flip pdf for thematic learning with the 'loving plants and animals' theme. This research used Research and Development method with Borg and Gall model. The data collecting procedures were through observation, interview, and documentation. The results indicated that The development of learning media professional flip pdf gained $94.54 \%$ from media experts with the very feasible category, material experts $86.66 \%$ with the very feasible category, and linguists $94.54 \%$ with a very feasible category. In addition, the average of teachers' response obtained was $95 \%$ with the very feasible category. The small-scale trial was $91.3 \%$, and the large-scale trial was obtained 95.8\%, both with very attractive interpretation criteria. Therefore, professional pdf flip-based learning media are very feasible and very interesting to be used as thematic learning media.
\end{abstract}

\begin{abstract}
Abstrak:
Pembelajaran tematik membutuhkan kreativitas guru dalam memilih dan mengembangkan media pembelajaran; salah satunya dengan menggunakan media pembelajaran flip pdf professional. Penelitian ini bertujuan untuk mengetahui kelayakan, respon guru dan siswa terhadap flip pdf profesional untuk pembelajaran tematik dengan tema 'menyayangi tumbuhan dan binatang'. Penelitian ini menggunakan metode Research and Development dengan model Borg and Gall. Teknik pengumpulan data dalam penelitian menggunakan observasi, wawancara, angket dan dokumentasi. Hasil penelitian menunjukkan bahwa pengembangan media pembelajaran flip pdf profesional diperoleh rata-rata $94,54 \%$ dari ahli media dengan kategori sangat layak, ahli materi 86,66\% dengan kategori sangat layak, dan ahli bahasa $94,54 \%$ dengan kategori sangat layak. Selain itu, rata-rata respon guru yang diperoleh adalah 95\% dengan kategori sangat layak. Uji coba skala kecil sebesar 91,3\% dan uji coba skala besar diperoleh 95,8\%, keduanya mendapat kriteria interpretasi sangat menarik. Denga demikian, media pembelajaran berbasis flip pdf profesional sangat layak dan sangat menarik untuk digunakan sebagai media pembelajaran tematik.
\end{abstract}

\section{Keywords:}

Thematic Learning, Professional Flip PDF, Learning Media

How to Cite: Fatonah, S. \& Yunianto, T. (2021). The Development of Professional Flip PDF Based Learning Media in Thematic Learning at the Third Grade Students of Elementary School. Lentera Pendidikan: Jurnal Ilmu Tarbiyah dan Keguruan, 24(1), 158-168. https://doi.org/10.24252/lp.2021v24n1i15. 


\section{INTRODUCTION}

Education is one of the most important parts of human development to increase the quality of resources in supporting life in the future (Zakiyah, 2014). An effective learning process and learning media can serve as facilities to achieve the required learning purpose (Sholichah, 2018). By the implementation of education, it is hoped that it can overcome the social problems that occur in the community. The government notices the efforts of education through the implemented curriculum (Chairul, 2017).

The curriculum is a set of plans and arrangements regarding the objectives, contents, learning materials, and methods used as guidelines in implementing the students' learning activities to achieve certain educational goals (Widyastono, 2014). The purpose of the curriculum is to encourage the students to be better in observing, asking, reasoning, and representing what they have gained after receiving the learning material at school (Rufiana, 2016). The current curriculum used is the curriculum 2013. It is a competencybased curriculum, which includes attitude competence, knowledge, and skills. Thematic learning is chosen as the basis for learning to achieve the formulated competencies (Suyatmini, 2017).

Thematic learning allows students both individually or as a group to actively explore and find concepts and principles holistically, meaningfully and authentically (Narti et al., 2015). Thematic learning is a learning concept that involves several subjects to provide meaningful experiences for students (Setiawan et al., 2019). Thematic learning is demanding the teachers' creativity in choosing and developing the learning themes. Thematic learning in the curriculum 2013 is expected that teachers can teach or at least show the students how technology is in the learning process, such as using interactive learning media based on applications (Hidayah, 2015). During the pandemic, thematic learning in the learning process uses a lot of learning media, the right learning media and a solution during the pandemic is professional flip pdf.

Learning media is a tool to improve the activities in the teaching and learning process so that there is a willingness to be more enthusiastic in following a learning process (Rahmi et al., 2019). The creativity in using learning media can facilitate and increase learning efficiency so that learning objectives can be achieved (Ramli, 2015). The advantages of learning media as a teaching method will be more diverse, not only verbal communication from the teacher. Therefore, students do not feel bored. The learning will attract the students' attention so that it can encourage their learning motivation, and learning material will be easier to be understood by the students (Arda et al., 2015). The function of learning media is to grow and encourage the students' regular and continuous thinking, especially through live images, enlarge the students' attention, help the development of students' language skills, and also provide real experiences that can stimulate the students' thinking (Arsyad, 2016).

Facts in the field based on interviews and questionnaires at MI Ma'arif Darussalam Plaosan Klaten show that educators rarely use practical, innovative, and diverse learning media that engage students. The lack of use of learning media applied to thematic learning in learning activities only focuses on theme books and teaching aids, and there is still a lack of skills in developing technology-based media. 
Based on those facts, it is necessary to have learning media through the new and interactive software form. One of them is professional flip pdf. Professional flip pdf is an Ebook maker software in the form of a flip-book (Watin, 2017). Professional flip pdf has the advantages of being able to input videos in a PDF, and also, it does not require an internet connection (Yunianto et al., 2019).

The previous research findings showed that the use of e-modules with a scientific approach by using professional flip pdf on square and rectangular materials were very effective to use in the mathematics learning process, and also this research provides feasibility and valid results (Agustina et al., 2021). In addition, 3D page flip development research provided valid results in electrolyte and non-electrolyte solutions (Utami, 2017). Moreover, there is RPS Flip builder development research that is aimed to improve students' understanding of science learning during the Covid-19 period. This research said that flip builder learning media on science (IPA) material was feasible and very practical to be used (Yunianto, 2021).

This research had a novelty that was the thematic learning with the theme "loving plants and animals" by using professional flip pdf. This research was expected to be a solution to teachers for being able to provide learning innovations. This study was aimed to determine the feasibility and response of teachers and students to learning media based on professional flip pdf.

\section{RESEARCH METHOD}

This type of research and development used a modified Borg and Gall model (Sugiyono, 2017). The steps could be seen in figure 1:
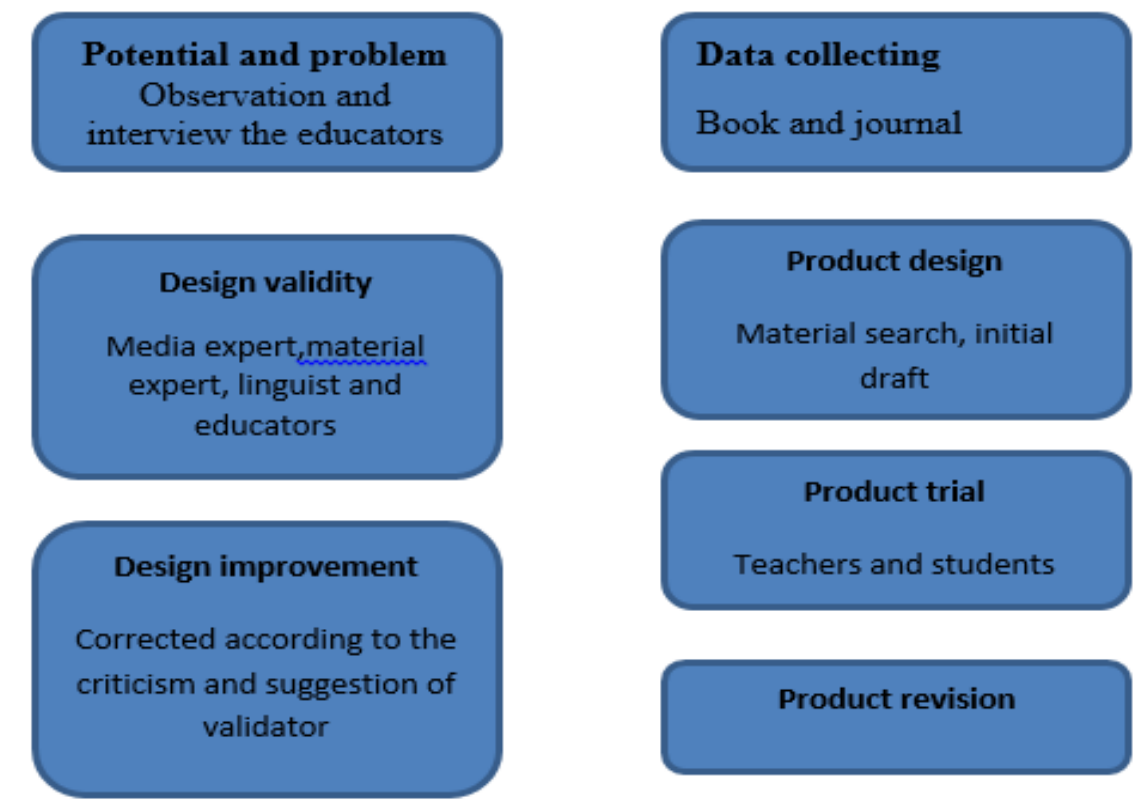

Figure 1. Research Design 
This study used the validation of media experts, materials experts, and linguists with one respondent. The subject of this study involved the third-grade students and educators at MI Ma'arif Darussalam Plaosan Klaten, small group trials consisting of 20 students while for large group trials consisting of 35 learners.

The data collection in this study was gathered by using observation, questionnaire, and documentation. The technique of data analysis in this research was a feasibility questionnaire. The analysis results used expert validation and teacher response sheets. The questionnaire used the Likert scale. The instrument had five answers described in table 1:

Table 1. Original Validity of Assessment Scale

\begin{tabular}{ll}
\hline Category & Score \\
\hline Excellent & 5 \\
Good & 4 \\
Average & 3 \\
Poor & 2 \\
Very poor & 1 \\
\hline
\end{tabular}

The total assessment score was calculated by using the following formula adapted from Latifa (2016):

$$
\mathrm{P}=\frac{f}{N} \times 100 \%
$$

Note:

$\mathrm{F}=$ Obtained Score

$\mathrm{N}=$ Total Frequency/ Maximum Score

$\mathrm{P}=$ Percentage

The average score of each expert validation was to determine the validity and feasibility of learning media.

Table 2. Criteria of Validity

\begin{tabular}{cll}
\hline \multicolumn{1}{c}{ No } & \multicolumn{1}{c}{ Percentage (\%) } & \multicolumn{1}{c}{ Criteria } \\
\hline 1 & $0-50$ & Very Inappropriate \\
\hline 2 & $50-60$ & Not Feasible \\
\hline 3 & $60-70$ & Less Feasible \\
\hline 4 & $70-80$ & Feasible \\
\hline 5 & $80-100$ & Very Feasible \\
\hline
\end{tabular}

The teachers' and students' response questionnaire had five answer choices. Each answer had a different score which indicated the level of product compatibility for the user. The score of each answer described in table 3. 
Table 3. The Assessment Score of Each Answer

\begin{tabular}{cc}
\hline Category & Score \\
\hline Strongly agree & 5 \\
\hline Agree & 4 \\
\hline Neutral & 3 \\
\hline Disagree & 2 \\
\hline Strongly disagree & 1 \\
\hline
\end{tabular}

The assessment scores from each teacher and student responses were used to find the mean score. The result then converted into five criteria that could be seen in Table 4 .

Table 4. Criteria of Validity

\begin{tabular}{lll}
\hline No & Percentage (\%) & \multicolumn{1}{c}{ Criteria } \\
\hline 1 & $0-50$ & Strongly not interested \\
\hline 2 & $50-60$ & Not interested \\
\hline 3 & $60-70$ & Neutral \\
\hline 4 & $70-80$ & Interested \\
\hline 5 & $80-100$ & Strongly Interested \\
\hline
\end{tabular}

\section{RESULTS AND DISCUSSION}

This research developed thematic learning media with the theme "loving plants and animals" using professional flip pdf. The result of this study indicated that:

\section{Potentials and Problems}

Potentials and problems in this research were observation and questionnaire conducted at MI Ma'arif Darussalam PLaosan Klaten, Central Java. Based on the analysis result, it showed that students' motivation in thematic learning was still low. Students felt boring and lack of motivation in thematic learning because there were no interactive learning media such as professional flip pdf. However, MI Ma'arif Darussalam has implemented the 2013 curriculum, so it is possible to be innovative in learning media.

\section{Collecting the Data}

One of the most important to develop professional flip pdf learning media is collecting the data and information. The development of professional flip pdf learning media in thematic learning was gathered from the references related to the material that would be learned. Therefore, it facilitated the assessment and determined the data of this research.

\section{Product Design}

Design of the learning media by flip pdf used letter paper with space 1.5, font size 12, font face times new roman, baohaus and cambria, upper margin size $4 \mathrm{~cm}$, left side 4 $\mathrm{cm}$, right side $3 \mathrm{~cm}$, and the bottom $3 \mathrm{~cm}$. Making design was begun by using Microsoft word, then converted the file from Microsoft word to pdf. The pdf inserted into a professional flip pdf application to be added animation videos and photos to support 
students' learning. The picture of professional flip pdf illustrated in figure 2,3 and 4:

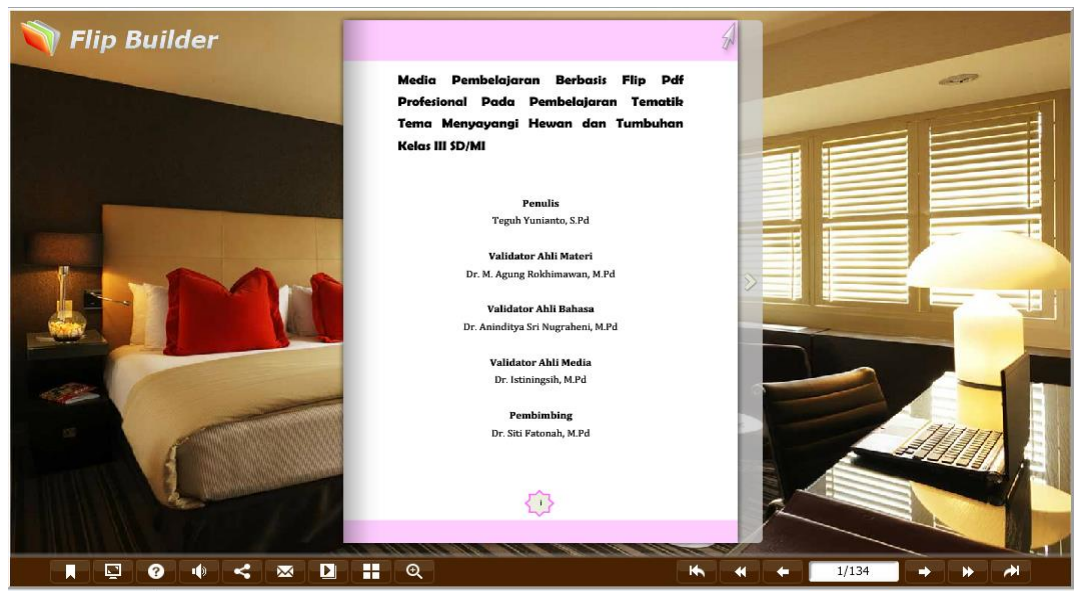

Figure 2. Cover Design

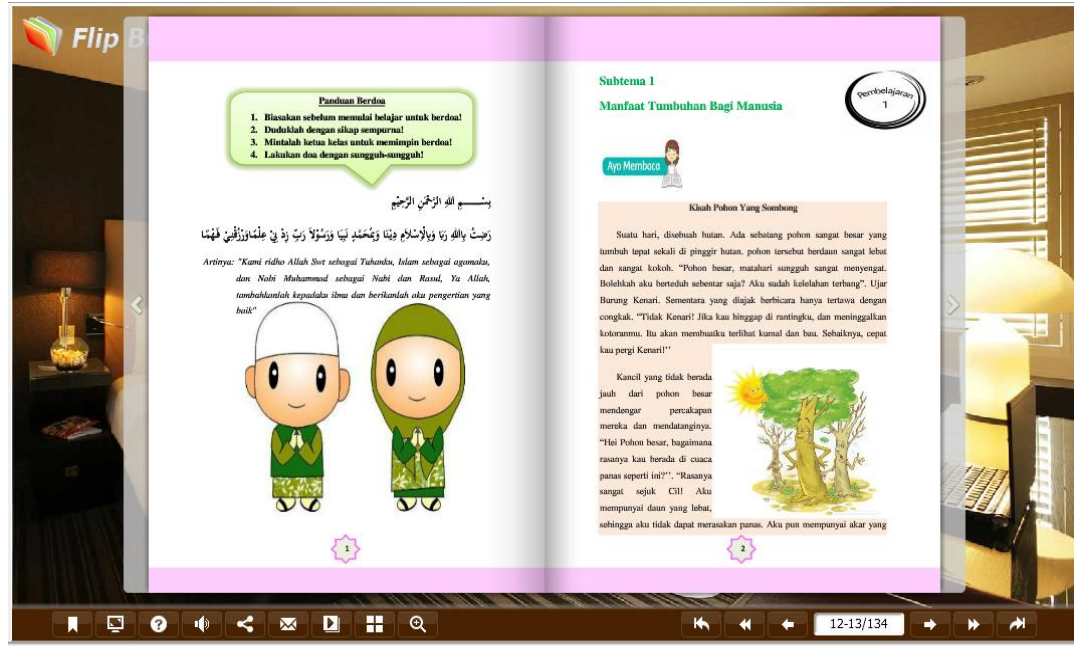

Figure 3. Material Design

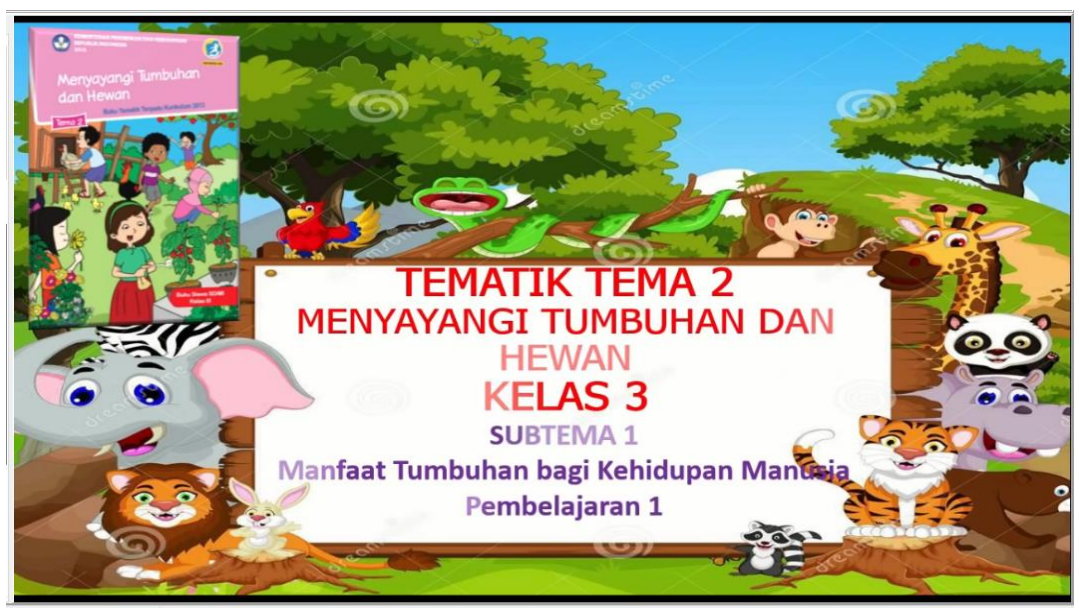

Figure 4. Video Design 


\section{Design Validity}

Validity was intended as a consideration for media experts, material experts, and linguists. Based on the experts' suggestion and instruction, it was expected to make a better and feasible media use. The results of the media expert's validity illustrated in figure 5.

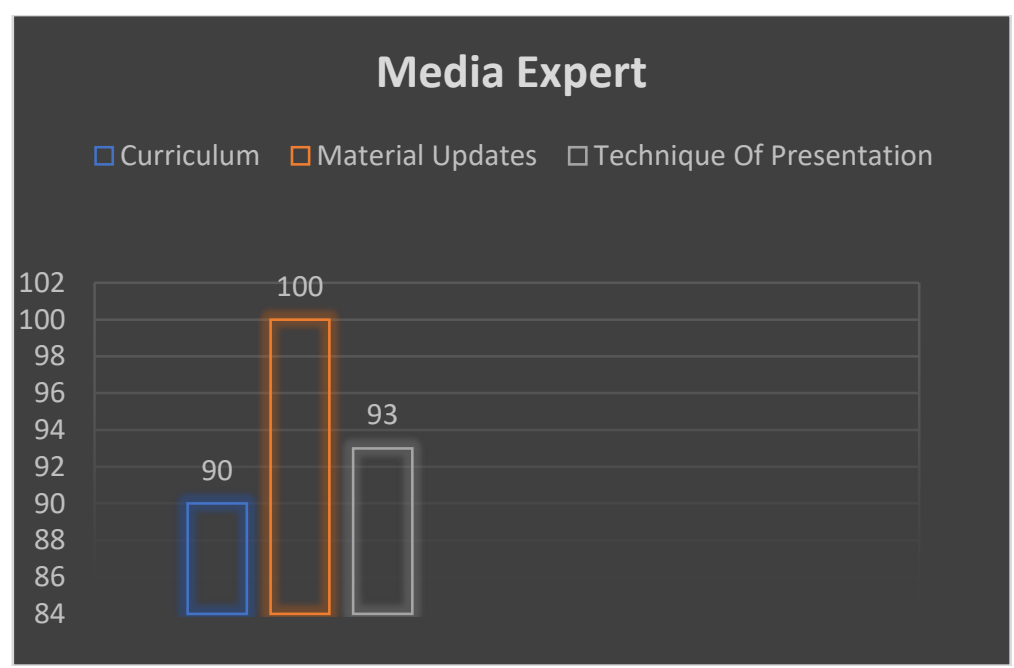

Figure 5. The Result of Media Expert Validity

Based on figure 5, the display/design aspect of the media obtained an average of $90 \%$, the average of media presentation aspect was $100 \%$, and the media aesthetical aspect had an average of $93.33 \%$. The overall average obtained on the media expert validation was $94.54 \%$, with the criteria "very feasible".

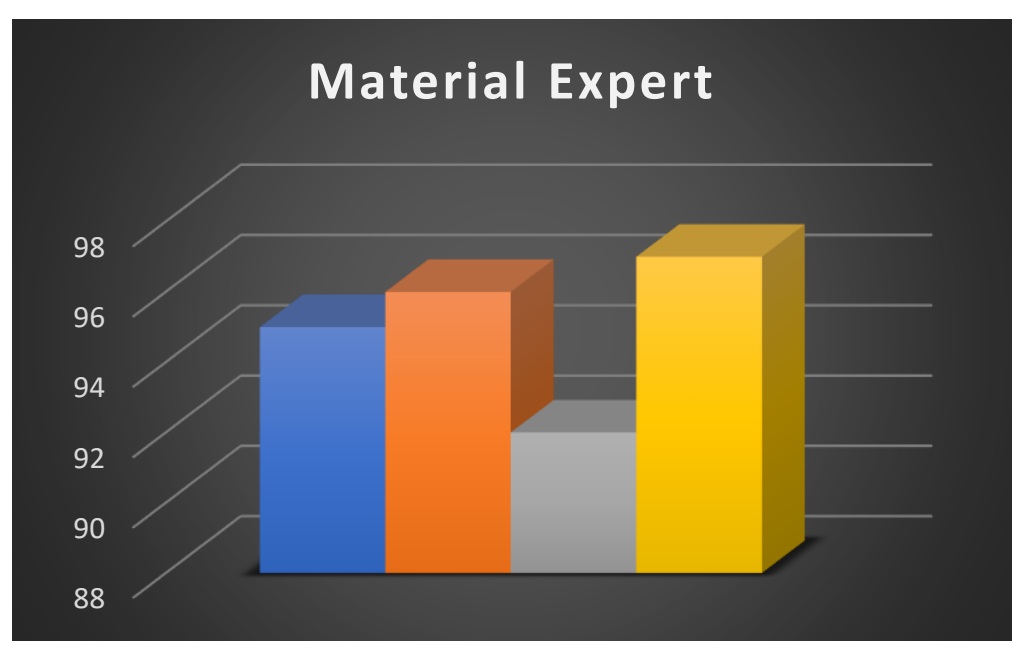

Figure 6. The Result of Material Expert Validity

Based on figure 6, the average curriculum aspect obtained was $86.66 \%$. The modern aspect of the material was $80 \%$ of average, the presentation technique aspect was $90 \%$ of average, and the contextual aspect was obtained $86.66 \%$ of average. The overall average obtained in the material expert validity was $86.66 \%$ with "very feasible" criteria. 


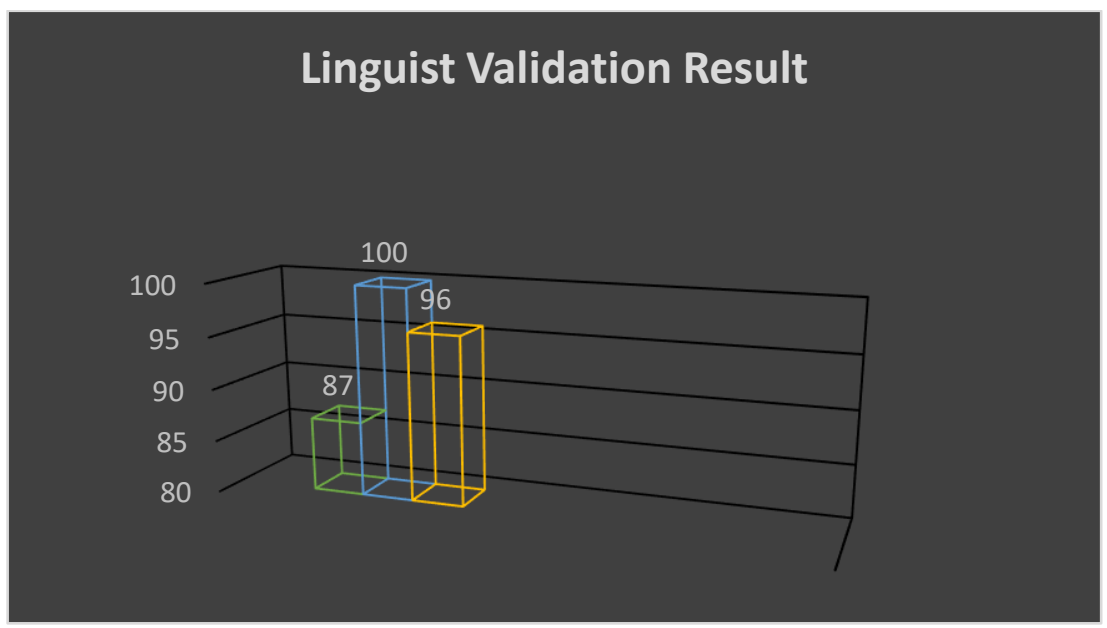

Figure 7. Linguist Validation Result

Based on figure 7, the average of dictions and language used aspect obtained was $86.66 \%$. Students' development's suitability aspect was gained $100 \%$, and the communicative aspect was obtained $96 \%$. The overall average in the linguist validation was $94.54 \%$, with the criteria "very feasible".

\section{Design Revision}

In this step, the revision was carried out based on the assessment of the material, linguist, and media expert validators toward the product that had been developed, namely professional flip pdf learning media. The table of the experts' suggestion described in table 5 and 6.

Table 5. The Validity of Suggestions from Material Experts

\begin{tabular}{cl}
\hline No & \multicolumn{1}{c}{ Suggestion/input } \\
\hline 1 & $\begin{array}{l}\text { It would be better to use a concept map to understand the material that had } \\
\text { been presented. }\end{array}$ \\
\hline 2 & The material mastery was still at the LOST level, not to the HOST level. \\
\hline \multicolumn{2}{c}{ Table 6. The Validity of Suggestions from Linguists } \\
\hline No & \multicolumn{1}{c}{ Suggestion/input } \\
\hline 1 & Correct typos. \\
\hline 2 & Correct the word that indicated a place. \\
\hline
\end{tabular}

\section{Product Trial}

The trial phase was carried out to determine the teachers' and students' responses in MI Ma'arif Darussalam Plaosan Klaten, Central Java. The results illustrated as follows: 


\section{Educator Response}
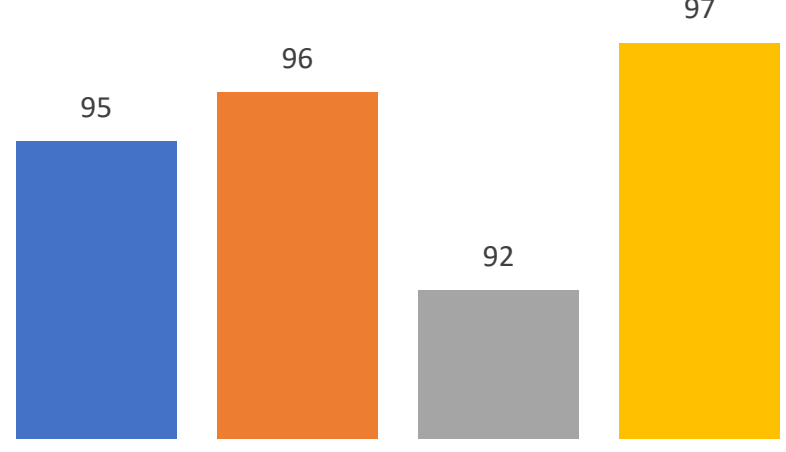

Figure 8. The Results of the Educators' responses

Based on figure 8, the average of educators' responses to the curriculum aspect was $95 \%$. The modern aspect obtained was $96 \%$, the aspect of media accuracy was $92.5 \%$, and the implementation aspect was $96.66 \%$. The overall average score obtained for teachers and practitioners was $95 \%$ with "very feasible" criteria.

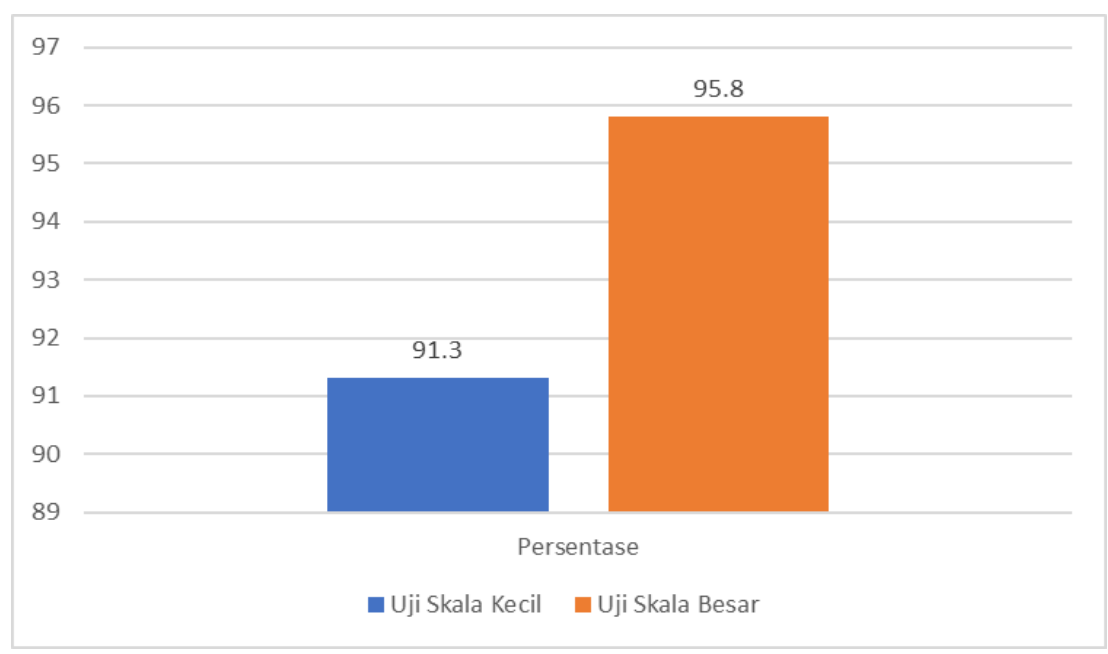

Figure 9. The Results of Students' Responses

The average of small group trials obtained was $91.3 \%$, with the criteria of very interesting interpretation. The results of large-scale trials had gained an average of $95.8 \%$, with the criteria of very interesting interpretation.

\section{Product Revise}

In this step, the product was not necessary to be revised. Based on the small and large scale product trials, professional flip pdf learning media was very interesting and very feasible to use as a media that could help the thematic learning process with the loving plants and animals theme. 


\section{CONCLUSION}

Based on the data analysis, the product produced in this research was professional flip pdf learning media using Research and Development (R \& D) method with Borg and Gall model. The development of learning media professional flip pdf gained $94.54 \%$ from media experts with the very feasible category, material experts $86.66 \%$ with the very feasible category, and linguists $94.54 \%$ with a very feasible category. In addition, the average of teachers' response obtained was $95 \%$ with the very feasible category. The small-scale trial was $91.3 \%$ with very attractive interpretation criteria, and the large-scale trial was obtained $95.8 \%$ with very attractive interpretation criteria. Thus, Professional flip pdf based learning media developed was very feasible and very interesting as a thematic learning media. However, it needs to be expanded to all grade levels in elementary school with different material.

\section{REFERENCES}

Agustina, T., - Hamdi, A. P., \& Syafriani. (2021). Physics E-Book Design for High School Students Using Flip Pdf Professional Based on Edupark Hot Waterboom Solok Selatan. Pillar of Physics Education 13 (4): 511-19. http://dx.doi.org/10.24036/9783171074.

Arda, Sahrul S., \& Darsikin. (2015). Pengembangan Media Pembelajaran Interaktif Berbasis Komputer untuk Siswa SMP Kelas VIII. Mitra Sains 3 (1): 69-77. https://media.neliti.com/media/publications/153834-ID-pengembangan-mediapembelajaran-interakt.pdf.

Arsyad, A. (2016). Media Pembelajaran. Jakarta: Pt Raja Grafindo Persada.

Chairul, A. Diva Press. (2017) Teori-Teori Pendidikan Klasik Hingga Kontemporer. Yogyakarta.

Hidayah, N. (2015). Pembelajaran Tematik Integratif di Sekolah Dasar. Terampil: Jurnal

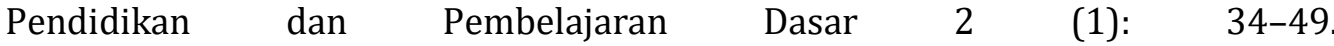
https://doi.org/10.24042/terampil.v2i1.1280.

Narti, Y., Punaji S., Degeng, I. N. S., \& Dwiyogo, W. D. (2015). Thematic Learning Implementation in Elementary School (Phenomenology Studies in Pamotan SDN 01 and 01 Majangtengah Dampit Malang) 5 (11): 7.

Putra, N. (2015). Research \& Development. Jakarta: Pt Raja Grafindo Persada.

Rahmi, Muntaha, M. S., M. Budiman, A. \& Widyaningrum, A. (2019). Pengembangan Media Pembelajaran Interaktif Macromedia Flash 8 pada Pembelajaran Tematik Tema Pengalamanku. International Journal of Elementary Education 3 (2): 178-85. http://dx.doi.org/10.23887/ijee.v3i2.18524.

Ramli, M. (2015). Media Pembelajaran dalam Perspektif Al-Qur'an Dan Al-Hadits 13: 25.

Rufiana, I. S. (2016). Level Kognitif Soal pada Buku Teks Matematika Kurikulum 2013 Kelas VII untuk Pendidikan 10. http://journal.umpo.ac.id/index.php/dimensi/article/view/153. 
Setiawan, A., Fajaruddin, S. \& Andini, D. W. (2019). Development an Honesty and Discipline Assessment Instrument in the Integrated Thematic Learning at Elementary School. Jurnal Prima Edukasia 7 (1): 9-19. https://doi.org/10.21831/jpe.v7i1.23117.

Sholichah, A. S. (2018). Teori-Teori Pendidikan dalam Al-Qur'an. Edukasi Islami: Jurnal Pendidikan Islam 7(1), 23-46. http://dx.doi.org/10.30868/ei.v7i01.209.

Sugiyono, S. (2017). Metode Penelitian Pendidikan Pendekatan, Kuantitatif, Kualitatif dan $R$ $\& D$. Bandung: Alfabeta.

Suyatmini, S. (2017). Implementasi Kurikulum 2013 pada Pelaksanaan Pembelajaran Akuntansi di Sekolah Menengah Kejuruan. Jurnal Pendidikan Ilmu Sosial 27 (1): 6068. http://journals.ums.ac.id/index.php/jpis/article/view/5120.

Utami, R. (2017). Pengembangan E-LKS Berbasis Metakognisi Menggunakan 3d Page Flip pada Materi Larutan Elektrolit dan Non-Elektrolit di Kelas X MIPA SMA Negeri 1 Muaro Jambi. Jurnal Pendidikan Kimia, October. https://repository.unja.ac.id/2184/.

Watin, E. (2017). Efektivitas Penggunaan E-Book dengan Flip Pdf Professional untuk Melatihkan Keterampilan Proses 6 Sains, https://fisika.fmipa.unesa.ac.id/proceedings/index.php/snf/article/view/25.

Widyastono, H. (2014). Pengembangan Kurikulum di Era Otonomi Daerah dari Kurikulum 2004, 2006 Ke Kurikulum 2013. Jakarta.

Zakiyah, Y. (2014). Pendidikan Nilai Kajian Teori Dan Praktiknya Di Sekolah. Bandung: Pustaka Setia.

Yunianto, T. (2021). Pengembangan Rps-Flip Builder untuk Meningkatkan Pemahaman IPA dalam Pembelajaran di Masa Covid-19. Jurnal Fundadikdas (Fundamental Pendidikan Dasar) 4(1): 1-8. https://doi.org/10.12928/fundadikdas.v4i1.3428.

Yunianto, T, Negara, H. S. and Suherman. (2019). 'Flip Builder : Pengembangannya pada Media Pembelajaran Matematika'. Terampil: Jurnal Pendidikan dan Pembelajaran Dasar 6(2): 115-27. https://doi.org/10.24042/terampil.v6i2.5056. 